Intanon $S$ et al. (2020)

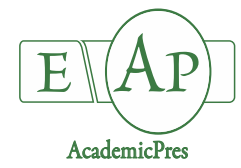

Notulae Botanicae Horti Agrobotanici Cluj-Napoca 48(1):261-272

DOI: $10.15835 /$ nbha48111831

Research Article

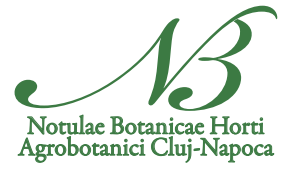

\title{
Seed morphology and allelopathy of invasive Praxelis clematidea
}

\author{
Suphannika INTANON ${ }^{1,2 *}$, Buntoon WIENGMOON³, \\ Carol A. MALLORY-SMITH ${ }^{4}$ \\ ${ }^{I}$ Naresuan University, Department of Agricultural Science, Phitsanulok 65000, \\ Thailand; suphannikai@nu.ac.th ("*orrespondingauthor) \\ ${ }^{2}$ Naresuan University, Faculty of Agriculture, Natural Resources and Environment, Center of Excellence in Research for Agricultural \\ Biotechnology, Phitsanulok 65000, Thailand \\ ${ }^{3}$ Naresuan University, Department of Physics, Faculty of Science, Phitsanulok 65000, Thailand; buntoonw@nu.ac.th \\ ${ }^{4}$ Oregon State University, Department of Crop and Soil Science, Oregon 97330, USA; carol.mallory-smith@oregonstate.edu
}

\begin{abstract}
Praxelis [Praxelis clematidea (Griseb.) R.M.King \& H.Rob.] is an invasive species that infests many agricultural systems globally, such as orchards, rubber plantations, and other economic crops. The purpose of this research was to study seed morphology, germination factors, and allelopathy of aboveground parts of $P$. clematidea. P. clematidea seeds are small, light, and possess pappi that allow them to be dispersed easily by wind or animals. Among four $P$. clematidea populations collected from different provinces in Thailand, the size of $P$. clematidea seeds ranged from 2.6 to $3.2 \mathrm{~mm}$ in length, 0.6 to $0.7 \mathrm{~mm}$ in width, and were $0.4 \mathrm{~mm}$ in thickness. The weight of $P$. clematidea seeds ranged from 0.13 to $0.21 \mathrm{mg}$. P. clematidea had about 44 to 48 seeds per head. Seeds germinated over a temperature range of 20 to $30^{\circ} \mathrm{C}$ while high $\left(45^{\circ} \mathrm{C}\right)$ and low $\left(10^{\circ} \mathrm{C}\right)$ temperatures reduced germination. Maximum germination occurred when seeds were planted on the soil surface. No seedlings germinated when seeds were planted at a depth more than $1 \mathrm{~cm} . P$. clematidea extracts from aerial plant parts at concentrations of 25 and $50 \%$ inhibited seedling growth of hairy beggarticks (Bidens pilosa L.). Basic knowledge of the seed biology of $P$. clematidea and allelochemicals can help in understanding the invasiveness and in developing management strategies for this weed.
\end{abstract}

Keywords: germination; invasive plant; morphology; planting depth; praxelis; temperature

\section{Introduction}

Invasive species are organisms that are exotic to an ecosystem (Monaco et al., 2002). They spread aggressively and may affect indigenous ecosystems and biodiversity. They cause negative effects on the environment as well as cause harm to the economy, and human health in the plant communities that they invade (Vitousek et al., 1996). These invasions can lead to alteration of ecology such as changes in species composition, changes in nutrient cycling, and increased forest fires (Sakai et al., 2001). 
Praxelis [Praxelis clematidea (Griseb.) R.M. King \& H. Rob.] together with about 13 other species of the Praxelis genus belongs to Asteraceae family (King and Robinson, 1987). It has been classified as an annual or short-lived perennial herb to suffrutescent shrub with a height of between 100 and $130 \mathrm{~cm}$. The stem is erect or branched from the base, and has soft pubescent. The leaves are ovate, rounded to cuneately narrowing at the base, irreglularly toothed margins with acute to obtuse apex. The flowers are in cylindrical head inflorescences (capitulescences) with conical receptacles. Primary capitulescence is a corymb while secondary capitulescence is a panicle with peduncle length up to $0.7 \mathrm{~cm}$. The involucres are subimbricate with 2-3 seriate bracts, and the phyllaries are deciduous during fruiting stage. The fruit is an obconical achene with bristle pappi (Abbott $e t$ al., 2008; Christ and Ritter, 2019). P. clematidea is fast growing and can produce numerous flowers and seeds within the first growing season. Seeds are small in size with a pappus that can help them to easily disperse by wind, animals, and farm machinery. $P$. clematidea has high adaptability and survives in a wide range of conditions (Veldkamp, 1999; Holland, 2006).

Praxelis is native to South America, and distributed throughout northern Argentina, southern Brazil, Bolivia, and Paraguay (King and Robinson, 1987). There were two Praxelis species found in southern Brazil, Praxelis clematidea and Praxelis missionum (Christ and Ritter, 2019). Waterhouse et al. (2003) previously reported the various habitats of invasive $P$. clematidea in Australia which included roadsides, stream banks, pastures, and also shady undisturbed woodlands. Veldkamp (1999) mentioned the difficulties in controlling $P$. clematidea due to its robust rootstock and long growing and flowering season. In addition to these characteristics, $P$. clematidea can form dense patches that are self-compatible and resistant to fire, all of which have helped to define $P$. clematidea as a high-risk weed in the USA (USDA, 2014). It has been reported as an invasive weed in many countries such as Australia (CRC Weed Management, 2003), China (Waterhouse et al., 2003), USA (Abbott et al., 2008; Gardner and Williges, 2015), and countries in Southeast Asia (Veldkamp, 1999). In Thailand, P. clematidea was first reported in 2003 in orchards and rubber plantations under the misidentified name of Chromolaena sp. (Plant Protection Research and Development, 2005) due to its similarity in leaf appearance to Siam weed [Chromolaena odorata (L.) R.M.King \& H.Rob.] (Anantanamanee et al., 2013). The biology and ecology of this species have been rarely studied in Thailand. Anantanamanee et al. (2013) reported that $P$. clematidea had better germination and growth in sandy soil and produced up to 1,400 seeds per plant in the first season.

Some invasive weed species become dominant due to their ability to produce biochemicals that native species have never encountered (Callaway and Ridenour, 2004). Allelopathy refers to the chemical interaction between plants, including microorganisms with both stimulatory and inhibitory influences (Rice, 1984), and allelopathic potential of plant species can influence the growth and distribution of other species (Rice, 1984; Inderjit and Keating, 1999). Allelopathy has been suggested as a vital mechanism for invasive species to outcompete native plants (Hierro and Callaway, 2003). Many plants in the Asteraceae family have allelopathic potential, and the activities, types, and amount of allelochemicals differ depending on plant species and plant parts (Chon and Nelson, 2010). In P. clematidea, allelochemicals have been reported as groups of sesquiterpenes and monoterpenes in volatile oil extracts from fresh aboveground plant extracts (Wang et al., 2006) and groups of flavonoids from dry and aboveground plant extracts (Maia et al., 2011; Falcão et al., 2013). The allelopathic potential of $P$. clematidea has not been extensively studied. Thepphakhun and Intanon (2016) showed that water extracts of fresh $P$. clematidea leaf tissues had the greatest inhibition of germination and growth of leaf mustard [Brassica juncea (L.) Czern.] and rice (Oryza sativa L.) compared to extracts from the stems and flowers. Patsai (2011) reported that water extracts from dry leaves of $P$. clematidea inhibited germination and growth of field mustard (Brassica campestris var. chinensis.), mission grass [Pennisetum polystachion (L.) Schult.], wild bush bean [Phaseolus lathyroides (L.) Urb.], rice, and mung bean [Vigna radiata 
(L.) Wilczek.]. To date, no studies have evaluated germination and growth inhibition by the combined aboveground tissues of $P$. clematidea on other plants.

Other factors supporting the invasion of $P$. clematidea remain unknown. $P$. clematidea only propagates by wind-dispersed seeds (Veldkamp, 1999), so seed morphology and germination factors are very important in the distribution and establishment of populations. Greater knowledge of $P$. clematidea biology such as seed morphology, germination factors, and plant allelochemicals may help to understand the invasiveness of $P$. clematidea and to develop suitable management strategies. The objective of this research, therefore, was to study the seed morphology and identification, germination factors, and allelopathy of aboveground parts of $P$. clematidea. The hypothesis of this study was that $P$. clematidea invades rapidly due to its ability to disperse and its allelopathic activity.

\section{Materials and Methods}

Praxelis characteristics and seed morphology

Morphology of seed, vegetative, and reproductive stages of $P$. clematidea were recorded. $P$. clematidea seeds were collected before shattering from four different locations in the Northern region of Thailand with no previous report of invasion, an orchard area in Chiang Mai Province (Sansai District, $18.916624^{\circ} \mathrm{N}$, $99.017832^{\circ} \mathrm{E}$ ), a rice field in Phetchabun Province (Wichian Buri District, $15.674403^{\circ} \mathrm{N}, 101.19486^{\circ} \mathrm{E}$ ), a cassava field in Kamphaeng Phet Province (Phran Kratai District, $16.735016^{\circ} \mathrm{N}, 99.429345^{\circ} \mathrm{E}$ ), and a maize field in Nan Province (Na Noi District, $\left.18.325981^{\circ} \mathrm{N}, 100.573042^{\circ} \mathrm{E}\right)$. P. clematidea seeds were cleaned by removing plant residues, air-dried, and kept in paper bags at room temperature until use.

A thousand $P$. clematidea seeds with the persistent pappi from the four different populations were weighed. A total of $100 \mathrm{P}$. clematidea seeds were counted in 10 replications and used to determine seed weight (ISTA, 2016). Seed size was determined by measuring the length (longest length without pappus), width (in the middle of seed), and thickness. A hundred replicate seeds were measured using a stereo microscope (SZX7 Olympus, Tokyo, Japan). The seed surface area was calculated by multiplying the length, width, and thickness. The number of seeds per head was recorded by randomly counting seeds on six heads per plant from five plants in each population.

To identify distinguishing characteristics of $P$. clematidea seeds and dispersal mechanisms from similar species in the same habitat of $P$. clematidea, a vegetation survey of Asteraceae species was conducted in a site of 0.8 ha maize field in Nan Province near areas of $P$. clematidea invasion. A sampling unit was a belt transect of $0.5 \times 100 \mathrm{~m}\left(50 \mathrm{~m}^{2}\right)$ which was placed across the field in three replications to represent weed floras of the sampling area. There were four dominant Asteraceae species, P. clematidea, tropic ageratum [Ageratum conyzoides (L.) L.], tall fleabane [Conyza sumatrensis (S.F. Blake) Pruski \& G.Sancho], and redflower ragleaf [Crassocephalum crepidioides (Benth.) S. Moore]. Seeds of the four species were collected, cleaned, and stored in paper bags. Seeds were weighed, and the seed surface area was estimated as previously described. Seeds of $A$. conyzoides were weighed with their persistent pappi while seeds of $C$. sumatrensis and C. crepidioides were weighed without pappi due to their nonpersistent pappi. The ratio of seed weight to surface area was calculated.

\section{Effects of temperature and depth on germination}

Germination tests were prepared for four P. clematidea populations, Chiang Mai (CM), Petchabun (PB), Kamphaeng Phet (KP), and Nan (NN) using the germination method of ISTA (2016). The CM population was used in this study due to its greater germination rate within 2 weeks after seed collection as compared to that of other populations which had germination rates less than $60 \%$. The effects of temperature 
and planting depth were conducted in the laboratory and the research field station, respectively, at Department of Agricultural Science, Naresuan University, Phitsanulok, Thailand.

Effect of temperature. Twenty-five P. clematidea seeds were placed in a Petri dish (Hycon Plastics, Bangkok, Thailand) and incubated at a constant temperature of $10,20,25,30$, or $45^{\circ} \mathrm{C}$ to evaluate the response to a wide range of germination temperatures. Petri dishes were placed in a growth chamber with a $12 \mathrm{~h}$ photoperiod. Seven days later, germination was counted as positive when the seedlings had a hypocotyl and/or a radical length of at least $2 \mathrm{~mm}$ (Intanon et al., 2014). The experiment was performed in a completely randomized design with four replications of each temperature. The experiment was conducted twice, and the means were averaged $(n=8)$.

Effect of planting depth. The method was modified from Peachey and Mallory-Smith (2007). Fifty $P$. clematidea seeds were placed in a $0.2 \mathrm{~mm}$ mesh nylon bag in order to avoid the loss of seeds. Seed bags were buried in polypropylene soil tubes in the late rainy season in October 2016 and October 2017. Meteorological data such as ambient temperature, relative humidity, and total precipitation were taken from a provincial weather station, Phitsanulok, Thailand, approximately $15.7 \mathrm{~km}$ from the study site (TMD, 2018). There were 28.4 and $28^{\circ} \mathrm{C}$ for average ambient temperature, 82 and $82 \%$ for relative humidity, and 186 and $128 \mathrm{~mm}$ precipitation during October 2016 and October 2017, respectively. The soil tubes were buried at 0, 1, 4, 7, and $10 \mathrm{~cm}$ below the soil surface. The soil tubes, $8 \mathrm{~cm}$ diameter and $10 \mathrm{~cm}$ height, were filled to a height of $6 \mathrm{~cm}$ with soil of the Taphan Hin series (Fine-silty, mixed, active, isohyperthermic Ultic Haplustalfs) mixed with soilless medium at a ratio of 1:1 in order to improve drainage. The soil was $28.6 \%$ sand, $21.4 \%$ silt, and $50 \%$ clay and was taken from a field that had no $P$. clematidea infestation. Each soil tube had twelve holes of a 5-mm size at the bottom of the tube to allow contact of the soil in the tube with the field soil. The seed bag was placed in the partially filled soil tubes, then covered with $1 \mathrm{~cm}$ of soil to a final depth in the soil tube of $7 \mathrm{~cm}$. The soil was moistened before the tubes were buried in the field. The seed bag was placed at the soil surface and sprinkled with a thin layer of soil (about $2 \mathrm{~mm}$ ) for the $0 \mathrm{~cm}$ depth. The soil tubes were placed in the field and watered throughout the study as needed to maintain adequate moisture. Average soil temperature during the studies was between 26 and $28^{\circ} \mathrm{C}$ (TGP-4500 Tinytag Plus 2, Micron Meters, Georgia, USA). Germination counts were recorded $30 \mathrm{~d}$ after planting. Germination was counted as positive as previously described. The experiment was performed in a completely randomized design with three replications of each depth. The experiment was conducted twice, and the means were averaged $(n=6)$.

\section{Allelopathic effect on germination and growth of $B$. pilosa}

Praxelis clematidea plants, all aboveground tissues, were collected during flowering from monospecific stands in Wangthong District, Phitsanulok Province, Thailand $\left(16.903787^{\circ} \mathrm{N}, 100.527014^{\circ} \mathrm{E}\right)$. The samples were cleaned and dried at $45^{\circ} \mathrm{C}$ for $72 \mathrm{~h}$, shredded into small pieces, and ground into a fine powder using an electric grinder and stored in paper bags until use. The seeds of hairy beggarticks (Bidens pilosa L.), an Asteraceae weed species were used as the test species due to their high percentage of germination $(>90 \%)$ and non-dormant seeds. Seeds of $B$. pilosa were collected from roadsides with no history of herbicide application in Muang District, Phitsanulok Province, Thailand $\left(16.735436^{\circ} \mathrm{N}, 100.194270^{\circ} \mathrm{E}\right)$. Seeds were cleaned with distilled water and sterilized with $2.5 \%$ sodium hypochlorite for $10 \mathrm{~min}$ to prevent fungal contamination, dried, and stored in paper bags until use. This study was conducted in the laboratory at Department of Agricultural Science, Naresuan University, Phitsanulok, Thailand.

A $10 \%(\mathrm{w} / \mathrm{v})$ P. clematidea extract was prepared in the proportion of $100 \mathrm{~g}$ of fine powder of $P$. clematidea in $1,000 \mathrm{ml}$ of distilled water and mixed at $100 \mathrm{rpm}$ for $5 \mathrm{~min}$ at $25^{\circ} \mathrm{C}$. The extract was filtered twice through two layers of $0.2 \mathrm{~mm}$ mesh cotton cloth and two layers of filter paper (Whatman No.1, Buckinghamshire, UK). Two extract dilutions, $25 \%(2.5 \% \mathrm{w} / \mathrm{v})$ and $50 \%(5 \% \mathrm{w} / \mathrm{v})$ were prepared by adding distilled water. Distilled water was used as a control. In addition to distilled water, different concentrations of polyethylene glycol 6000 (PEG 6000, Kemaus, New South Wales, Australia) solutions were included as 
controls to test for the possible osmotic effects of the extracts. The osmotic potential of each extract concentration was measured with a vapor pressure osmometer (Vapro 5600, Wescor Inc. Logan, UT, USA). Concentrations of 9.5 and $13.1 \%$ of polyethylene glycol were included as osmotic potential controls for extract concentrations of 25 and $50 \%$, respectively.

Sixteen seeds of $B$. pilos $a$ were placed in a $9 \mathrm{~cm}$ diameter Petri dish lined with one filter paper. From each extract concentration, $5 \mathrm{ml}$ were added to each Petri dish. Petri dishes were placed in a growth chamber at 25 ${ }^{\circ} \mathrm{C}$ with a $12 \mathrm{~h}$ photoperiod. After $7 \mathrm{~d}$, germination and root and shoot lengths were measured. Germination was counted as positive as previously described. The experiment was performed in a completely randomized design with three replications of each concentration. The experiment was conducted twice, and the means were averaged $(n=6)$.

\section{Statistical analyses}

There were no significant differences based on the Levene's ANOVA test for homogeneity of variances for germination studies which were conducted twice; therefore, data were pooled across studies and means were averaged. At the end of the germination period, the germination percentage was calculated using the following equation:

Germination Percentages (\%) $=($ Number of germinated seeds $) /($ Total number of seeds $) \times 100$

Inhibition percentage (IP) in allelopathic study was obtained by using the following equation: $\mathrm{IP}=100-(\mathrm{T} \times 100 / \mathrm{C})$

where $\mathrm{T}$ represents response of treatment and $\mathrm{C}$ is response of untreated control.

Data of germination percentage, shoot and root lengths, and seed morphology of $P$. clematidea and other weed species were analyzed by ANOVA. Means were separated using Tukey's HSD at $\mathrm{p}<0.05$. All statistical analyses were performed using the program R v. 3.5.0 (R Core Team, 2018).

\section{Results and Discussion}

Praxelis characteristics and seed morphology

Misidentification of $P$. clematidea with other related species in the same family has caused inaccurate invasion reports (Corlett and Shaw, 1995; Veldkamp, 1999; Holland, 2006; USDA, 2014). P. clematidea was mistaken for bluemink (Ageratum houstonianum Mill.), A. conyzoides, and Conoclinium coelestinum (L.) DC. (Veldkamp, 1999; Abbott et al., 2008). Therefore, P. clematidea was characterized at various stages for more accurate identification. In the seedling stage, $P$. clematidea has cotyledon leaves which are kidney-shaped that may dry up and fall off as seedlings mature (Figure 1A). The true leaves of $P$. clematidea are coarsely toothed leaf margins, oppositely arranged along the cylindrical stem, which is covered in short soft hairs (Figure 1B). When plant parts are crushed, they emit an odor similar to cat urine. The leaves of $P$. clematidea have more coarsely toothed margins and more tapered bases than those of $A$. conyzoides, which have smooth teeth along the edges and a rounded leaf base (CRC Weed Management, 2003; Holland, 2006; Abbott et al., 2008).

Praxelis clematidea has a unique characteristic of a lilac to intense blue inflorescence with deciduous bracts at the ends of stems and flowers with clusters of up to 48 florets (Table 1; Figure 1B). The flower of the $A$. conyzoides is pale blue or pale lilac with persistent bracts. The florets of $P$. clematidea are set in a high coneshaped receptacle while those of $A$. conyzoides are set in a flat receptacle (CRC Weed Management, 2003; Holland, 2006; Abbott et al., 2008). The phyllaries of $P$. clematidea has conspicuous dark striations from the veins (Abbott et al., 2008; Gardner and Williges, 2015).

Each $P$. clematidea floret produces one seed. The $P$. clematidea seed has an angular shape, hairy on the seed surface, and the seed color turns from brown to black during ripening (Figure 1C). Seed thickness from 


\section{6}

the 4 populations was $0.4 \mathrm{~mm}$ and no differences were found among populations $(\mathrm{p}>0.05)$ (Table 1). Seed weight, length, and width were somewhat different among populations. Seed weight and length were greatest in the Nan population which were $0.2 \mathrm{mg}$ and $3.2 \mathrm{~mm}$, respectively, and seed width was greatest in Phetchabun population at $0.7 \mathrm{~mm}$ (Table 1). Seed size and seed surface can be used to distinguish between $P$. clematidea and $C$. odorata. Seeds of $C$. odorata were narrower than $P$. clematidea with 0.2 to $0.8 \mathrm{~mm}$ width, 3 to $5 \mathrm{~mm}$ length, and without hairs on seed surface (Groenewegen et al., 2017). P. clematidea's pappus is longer than the length of its seed, which can be used to identify the species. A previous study reported $P$. clematidea had about 15 to 40 bristles of pappus while the similar species, A. conyzoides, had only 5 bristles (CRC Weed Management, 2003).

The number of $P$. clematidea seeds per head ranged from 44 to 48 seeds among the four populations of Thailand. Corlett and Shaw (1995) reported that P. clematidea in Hong Kong had about 50 to 65 seeds per head. Small-seeded species are able to produce many more seeds than large-seeded species (Moles et al., 2005). Important characteristics that make weeds successfully disperse and establish in new areas are seed characteristics such as a high number of seeds, a small seed size, and seed hair. $P$. clematidea can invade new areas easily because the plant can reach maturity in 30 to $35 \mathrm{~d}$ after emergence and produce the first seed set within 45 to $50 \mathrm{~d}$ after emergence (Anantanamanee $e t$ al., 2013). Flowers of $P$. clematidea can be produced year round, and the seeds are not dormant. Due to these characteristics of high productivity, $P$. clematidea has been reported as an invasive plant in many countries in Asia and in Australia (Veldkamp, 1999; CRC Weed Management, 2003; Waterhouse, 2003) and was characterized as an invasive alien species in Thailand (THBIF, 2018).

Praxelis clematidea had the smallest ratio of weight to surface area when compared to $A$. conyzoides, $C$. sumatrensis and $C$. crepidioides (Table 2). The smaller ratio of $P$. clematidea means that the seeds of $P$. clematidea persists longer in the air compared to other three species. The small seed size of $P$. clematidea with a persistent pappus can help extend dispersal distance via wind. A small seed with low weight to surface area was reported to result in a slow descent rate (Meyer and Carlson, 2001). However, in addition to wind, seeds of $P$. clematidea can be distributed by water, animals, and birds (CRC Weed Management, 2003).

Table 1. Seed morphological characteristics of four populations (Pop) of Praxelis clematidea collected from four Thailand Provinces, Chiang Mai (CM), Petchabun (PB), Kamphaeng Phet (KP), and Nan (NN)

\begin{tabular}{|c|c|c|c|c|c|c|c|c|c|c|}
\hline Pop & \multicolumn{2}{|c|}{ Weight $^{\mathrm{a}}(\mathrm{mg})$} & \multicolumn{2}{|c|}{ Length $(\mathrm{mm})$} & \multicolumn{2}{c|}{ Width $(\mathrm{mm})$} & \multicolumn{2}{|c|}{ Thickness $(\mathrm{mm})$} & \multicolumn{2}{c|}{ Seeds per head } \\
\hline CM & 0.13 & $\pm 0.001 \mathrm{c}$ & 2.79 & $\pm 0.01 \mathrm{bc}$ & 0.65 & $\pm 0.02 \mathrm{~b}$ & 0.4 & $\pm 0.01 \mathrm{~ns}^{\mathrm{b}}$ & 48 & $\pm 1.2 \mathrm{~ns}$ \\
\hline $\mathrm{PB}$ & 0.14 & $\pm 0.001 \mathrm{c}$ & 2.83 & $\pm 0.02 \mathrm{~b}$ & 0.73 & $\pm 0.01 \mathrm{a}$ & 0.4 & \pm 0.03 & 46 & \pm 1.1 \\
\hline $\mathrm{KP}$ & 0.17 & $\pm 0.005 \mathrm{~b}$ & 2.55 & $\pm 0.11 \mathrm{c}$ & 0.65 & $\pm 0.02 \mathrm{~b}$ & 0.4 & \pm 0.03 & 44 & \pm 1.2 \\
\hline $\mathrm{NN}$ & 0.21 & $\pm 0.003 \mathrm{a}$ & 3.20 & $\pm 0.20 \mathrm{a}$ & 0.64 & $\pm 0.03 \mathrm{~b}$ & 0.4 & \pm 0.02 & $-{ }^{\mathrm{c}}$ & \\
\hline
\end{tabular}

${ }^{a}$ Different letter between populations denote significantly differences (Tukey's HSD, $<<0.05$ ). Data are shown as mean \pm SE. ${ }^{b}$ Not significant. ${ }^{c}$ Data for number of seeds per head are not available for the Nan population.

Table 2. Seed weights, areas, and ratio of weight to surface area of Praxelis clematidea and other invasive Asteraceae weeds in Nan Province, Thailand

\begin{tabular}{|c|c|c|c|c|c|}
\hline Species & \multicolumn{2}{|c|}{ Weight $^{\mathrm{a}}(\mathrm{mg})$} & \multicolumn{2}{|c|}{ Surface area $\left(\mathrm{mm}^{2}\right)$} & Weight:surface area $\left(\mathrm{mg} \mathrm{mm}^{-2}\right)$ \\
\hline Praxelis clematidea & 0.208 & $\pm 0.003 \mathrm{~b}$ & 0.798 & $\pm 0.071 \mathrm{a}$ & 0.261 \\
\hline Ageratum conyzoides & 0.107 & $\pm 0.003 \mathrm{c}$ & 0.375 & $\pm 0.032 \mathrm{~b}$ & 0.286 \\
\hline Conyza sumatrensis & 0.032 & $\pm 0.003 \mathrm{~d}$ & 0.091 & $\pm 0.009 \mathrm{c}$ & 0.354 \\
\hline Crassocephalum crepidioides & 0.223 & $\pm 0.006 \mathrm{a}$ & 0.698 & $\pm 0.051 \mathrm{a}$ & 0.320 \\
\hline
\end{tabular}

${ }^{a}$ Different letters between species denote significantly differences (Tukey's HSD, p $<0.05$ ), $n=10$. Data are shown as mean \pm SE. 

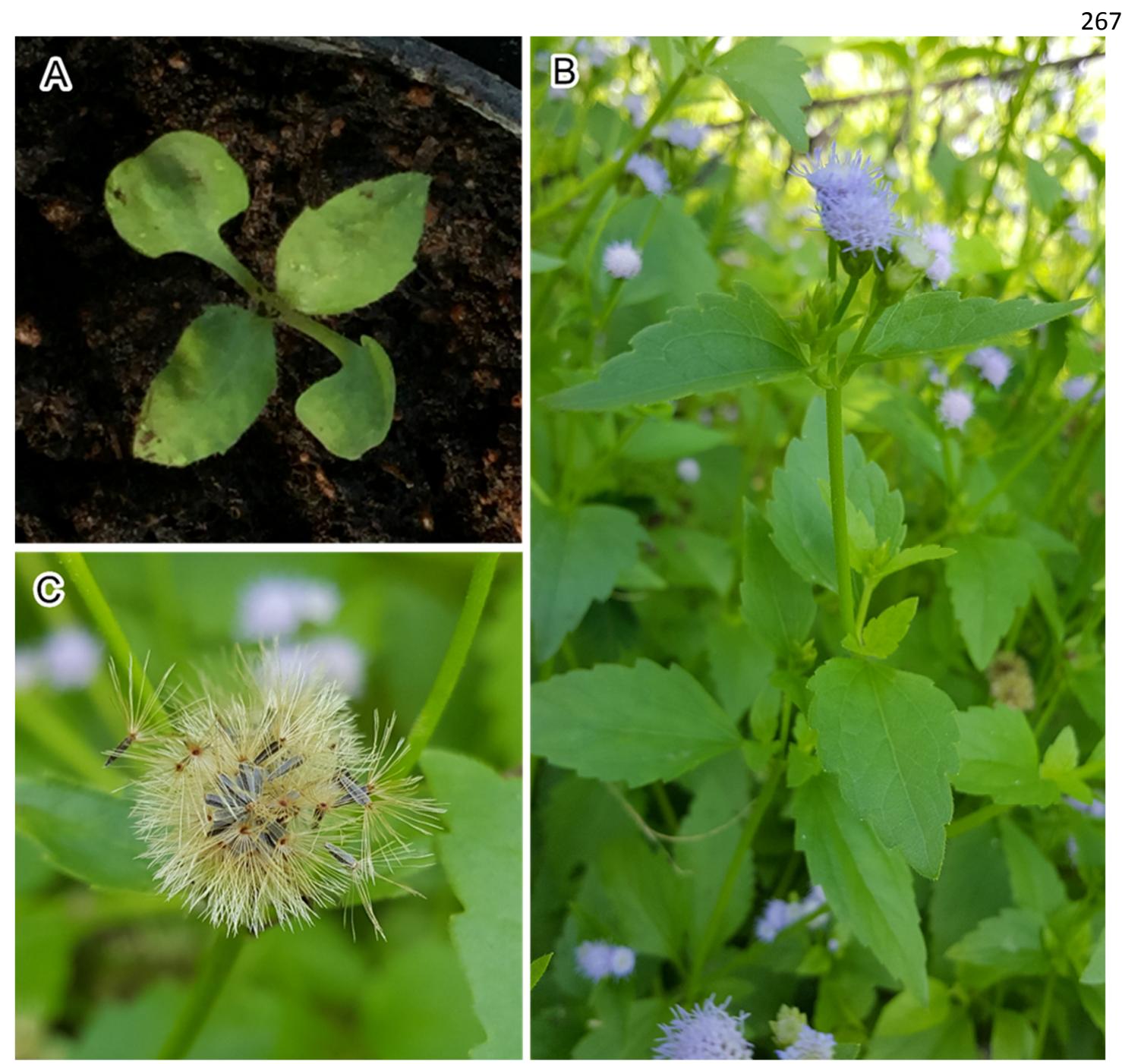

Figure 1. Morphology of Praxelis clematidea; seedling (A), leaves and inflorescences (B), and seeds (C)

\section{Effects of temperature and depth on germination}

Praxelis clematidea can germinate at various temperatures. To determine the effect of temperature, $P$. clematidea seeds were incubated at $10,20,25,30$, and $45^{\circ} \mathrm{C}$. The results showed that the seeds germinated at 20,25 , and $30^{\circ} \mathrm{C}$, but no germination was observed at 10 and $45^{\circ} \mathrm{C}$ (Figure 2.). Many tropical and subtropical plants require relatively high temperatures to initiate growth meanwhile relatively high temperatures $\left(\geq 35^{\circ} \mathrm{C}\right)$ inhibit germination of some plant species such as crofton weed [Ageratina adenophora (Spreng.) R. M. King \& H. Rob.] (Lu et al., 2006), C. crepidioides (Chen et al., 2009; Yuan and Wen, 2018), and horseweed (Erigeron canadensis L.) (Yuan and Wen, 2018). The fact that $P$. clematidea seeds were able to germinate over a temperature from 20 to $30^{\circ} \mathrm{C}$ allows it to grow all year round in Thailand as well as in tropical and subtropical region elsewhere.

The effect of soil depth on germination was studied by burying seed bags at $2 \mathrm{~mm}, 1 \mathrm{~cm}, 4 \mathrm{~cm}, 7 \mathrm{~cm}$, and $10 \mathrm{~cm}$ below the soil surface. The germination of $P$. clematidea seedlings decreased with increasing burial depth (Figure 3.). Germination was $77 \%$ for seeds placed on the soil surface and $18 \%$ for seeds placed $1 \mathrm{~cm}$ below the soil surface. No P. clematidea seed germination was observed when seeds were placed at a depth of $4 \mathrm{~cm}$ or greater. Planting depth affects seed dormancy and survival (Peachey and Mallory-Smith, 2017). In light- 
sensitive species such as lettuce (Lactuca sativa L.), a daylight exposure could induce seed germination at 2-mm depth below the soil surface but did not affect germination at 6-mm depth (Woolley and Stoller 1978). In some species, seeds could enter dormancy when buried near the soil surface such as wild proso millet (Panicum miliaceum L.) (Calosi et al., 1986) and redroot pigweed (Amaranthus retroflexus L.) (Omami et al., 1999). No seedlings of $A$. houstonianum emerged from seeds places more than 2-mm depth below the soil surface (Lamsal et al., 2019). The seedling emergence of coatbuttons [Tridax procumbens (L.) L.] decreased drastically with increasing burial depth due to limited light penetration (Vanijajiva, 2014). This study suggests that $P$. clematidea could be controlled by covering the seed with at least $4 \mathrm{~cm}$ of soil.

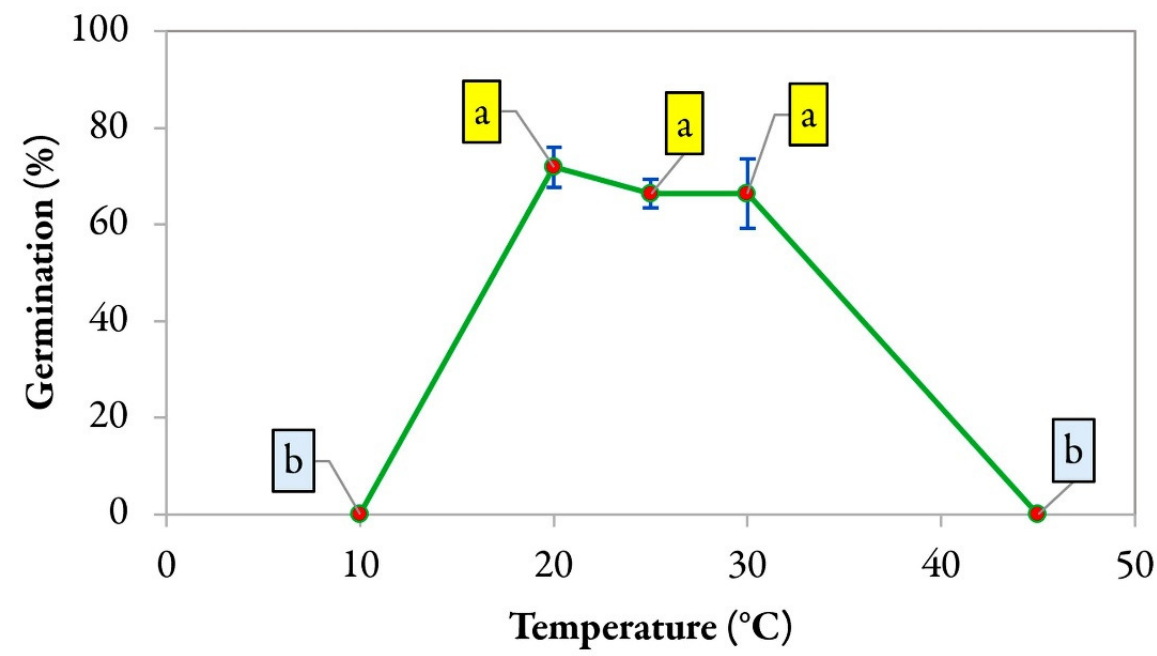

Figure 2. Effect of temperature on germination of Praxelis clematidea seeds. Verticle bars represent SE of the means, $n=8$. Different letters indicate significant differences (Tukey's HSD, $\mathrm{p}<0.05$ )

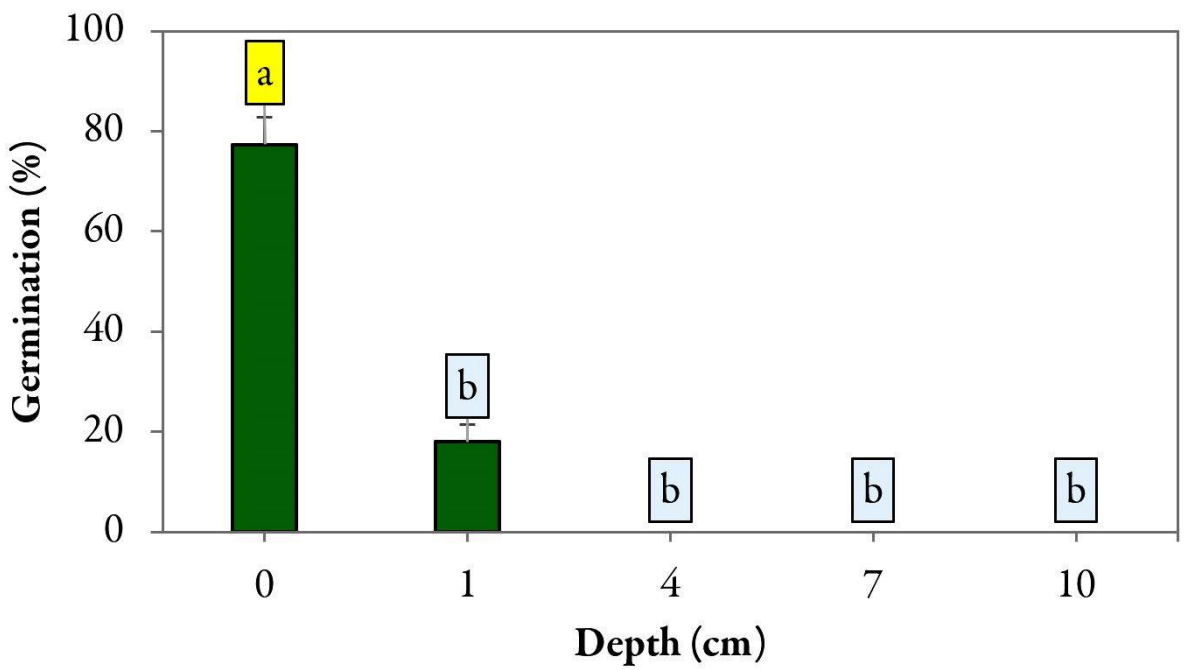

Figure 3. Effect of planting depth on germination of Praxelis clematidea seeds. Vertical bars represent SE of the means, $n=6$. Different letters indicate significant differences (Tukey's HSD, $\mathrm{p}<0.05$ ) 
Allelopathic effect on germination and growth of B. pilosa

Praxelis clematidea can be found as a dominant species or in monospecific stands. This has led to the hypothesis that $P$. clematidea produces allelochemicals which allow it to outcompete other nearby species. To evaluate this hypothesis, seeds from $B$. pilosa were treated with aerial plant extracts of $P$. clematidea. A preliminary study of the osmotic effects of $P$. clematidea extracts showed that the highest PEG concentration of $13.1 \%$ (equal to osmotic potential of $P$. clematidea at $50 \%$ concentration) did not significantly affect the germination and seedling length of $B$. pilosa compared to the untreated control $(\mathrm{P}>0.05)$. Therefore, it suggested that the observed effects of $P$. clematidea extracts of 25 and $50 \%$ concentrations on $B$. pilosa would be due to allelopathy and not osmotic stress. After $7 \mathrm{~d}$, the results showed allelopathic potential of $P$. clematidea extracts to suppress seedling growth of $B$. pilosa (Table 3). At $25 \%$ concentration, root and shoot length of $B$. pilos $a$ were reduced by 48 and $31 \%$, respectively, compared to the untreated control. At $50 \%$ concentration, root and shoot length of $B$. pilosa were reduced by 76 and $62 \%$, respectively, compared to the untreated control. The root growth of $B$. pilosa was more sensitive to the allelochemicals of $P$. clematidea compared to shoot growth. Abnormalities were observed in that there were twisted hypocotyls and oxidation and discoloration of the root cap at extracts 25 and 50\% concentrations. Miller (1996) stated that seedling growth, especially root growth, is more sensitive to allelochemicals than is germination. Previous studies have shown that volatile oil of $P$. clematidea can inhibit the growth of lettuce and field mustard (Brassica rapa L. cv. gr. 'Caixin'), and fungi (Wang et al., 2006). The mechanism of action of $P$. clematidea aerial extracts to suppress germination of other species is unknown. In general, allelochemicals affect many physiological processes in plants such as cell division and elongation, membrane permeability, oxidative and antioxidant systems, enzyme synthesis and metabolism, protein and nucleic acid synthesis (Cheng and Cheng, 2015). Allelochemicals that inhibit seed germination can be related to the inhibition of plant metabolism by decreasing activity of enzymes involved in early stages of seed germination such as $\alpha$-amylase, isocitrate lyase, glucose-6-phosphate dehydrogenase, glucose-phosphate isomerase, and aldolase (Gniazdowska and Bogatek, 2005).

Table 3. Effect of $P$. clematidea extracts on germination and growth of B. pilosa (BIDPI)

\begin{tabular}{|c|c|c|c|c|c|c|}
\hline Concentration $^{\mathrm{a}}$ & \multicolumn{2}{|c|}{ Germination $^{\mathrm{b}}(\%)$} & \multicolumn{2}{|c|}{ Root length $(\mathrm{cm})$} & \multicolumn{2}{|c|}{ Shoot length $(\mathrm{cm})$} \\
\hline 0 & 90.6 & $\pm 2.68 \mathrm{~ns}^{\mathrm{c}}$ & 2.1 & $\pm 0.08 \mathrm{a}$ & 1.3 & $\pm 0.07 \mathrm{a}$ \\
\hline $25 \%$ & 91.7 & \pm 3.49 & 1.1 & $\pm 0.12 \mathrm{~b}$ & 0.9 & $\pm 0.09 \mathrm{~b}$ \\
\hline $50 \%$ & 71.9 & \pm 10.43 & 0.5 & $\pm 0.10 \mathrm{c}$ & 0.5 & $\pm 0.07 \mathrm{c}$ \\
\hline
\end{tabular}

${ }^{\mathrm{a}}$ Concentration of aerial extracts of $P$. clematidea by water. Percentages are on $\mathrm{w} / \mathrm{v}$ basis. ${ }^{\mathrm{b}}$ Different letters between concentrations denote significantly differences (Tukey's HSD, $\mathrm{p}<0.05$ ), $n=6$. Data are shown as mean \pm SE. ${ }^{\mathrm{c}}$ Not significant.

\section{Conclusions}

Results of this study confirmed that seed morphology of praxelis can be used to distinguish between related species such as Ageratum spp. and Chromolaena spp. P. clematidea germination occurred in a temperature range of 20 to $30{ }^{\circ} \mathrm{C}$, and at a soil depth of up to $1 \mathrm{~cm}$. Furthermore, P. clematidea had characteristics, such as a small seed with a pappus, prolific seed production, no seed dormancy period, and allelopathic effects that help increase its distribution in the environment. It is predicted that this weed has the ability to invade most of the area of Thailand under a range of moisture and soil conditions as long as seed remains on the soil surface. Effective $P$. clematidea control should be undertaken at an early stage before flowering by using integrated weed control methods such as tilling plus a PRE or early POST herbicide. Decreasing the $P$. clematidea seed bank should be added to management programs. The grower should clean 
tools and machinery well to prevent the spread of $P$. clematidea to new areas. Plant identification and more information on the biology and ecology of $P$. clematidea would be useful in preventing the spread of this species.

\section{Acknowledgements}

The project was financially supported by Naresuan University Research Fund No. R2559C114. The authors are grateful to Professor Dr. Duncan R. Smith (Institute of Molecular Biosciences, Mahidol University, Thailand) for English editing and scientific proofreading of this manuscript. Thanks to Center for Agricultural Biotechnology, Kasetsart University, Kamphaeng Saen Campus, Thailand for help in measuring osmotic potential. Further thanks to Kanokwan Namwong for help in the fieldwork.

\section{Conflict of Interests}

The authors declare that there are no conflicts of interest related to this article.

\section{References}

Abbott J, White CL, Davis S (2008). Praxelis clematidea (Asteraceae), a genus and species new for the flora of North America. Journal of the Botanical Research Institute of Texas 2:621-626.

Anantanamanee Y, Maneechote C, Sathuwijarn S, Chaokongchak S (2013). Biology and ecology of praxelis (Praxelis clematidea R.M.King \& $\quad$ H.Rob.) (in Thai). Retrieved 2016 January 28 from http://www.doa.go.th/research/attachment.php?aid $=1969$

Callaway RM, Ridenour WM (2004). Novel weapons: invasive success and the evolution of increased competitive ability. Frontiers in Ecology and the Environment 2:436-443.

Calosi JC, Cavers PB, Bough MA (1986). Dormancy and survival in buried seeds of proso millet (Panicum miliaceum). Canadian Journal of Botany 66:161-168.

Chen GQ, Guo SL, Huang QS (2009). Invasiveness evaluation of fireweed (Crassocephalum crepidioides) based on its seed germination features. Weed Biology and Management 9:123-128.

Cheng F, Cheng Z (2015). Research progress on the use of plant allelopathy in agriculture and the physiological and ecological mechanisms of allelopathy. Frontiers in Plant Science 6:1-16.

Chon SU, Nelson CJ (2010). Allelopathy in Compositae plants. A review. Agronomy for Sustainable Development 30:349-358.

Christ A, Ritter M (2019). A taxonomic study of Praxelinae (Asteraceae-Eupatorieae) in Rio Grande do Sul, Brazil. Phytotaxa 393:141-197.

Corlett RT, Shaw JC (1995). Praxelis clematidea: yesterday South America, today Hong Kong, tomorrow the world? Memoirs of the Hong Kong Natural History Society 20:235-236.

CRC Weed Management (2003). Weed management guide: Praxelis-Praxelis clematidea. Retrieved 2016 December 7 from https://www.environment.gov.au/biodiversity/invasive/weeds/

Falcão HS, Maia GLA, Bonamin F, Kushima H, Moraes TM, Lima CAH, ... Batista LM (2013). Gastroprotective mechanisms of the chloroform and ethyl acetate phases of Praxelis clematidea (Griseb.) R.M. King \& H.Robinson (Asteraceae). Journal of Natural Medicines 67:480-491.

Gardner AG, Williges KA (2015). Praxelis clematidea (Asteraceae): a new plant invader of Florida. Southeastern Naturalist 14:N21-N27.

Gniazdowska A, Bogatek R (2005). Allelopathic interactions between plants. Multi-site action of allelochemicals. Acta Physiologiae Plantarum 27:395-407.

Groenewegen T, Duistermaat H, van Valkenburg JLCH, Boer E (2017). Seeds of invasive plants. Retrieved 2019 July 15 from https://keys.lucidcentral.org/keys/v3/invasive_seeds 
Hierro JL, Callaway RM (2003). Allelopathy and exotic plant invasion. Plant and Soil 256:29-39.

Holland A (2006). Praxelis (Praxelis clematidea R.M.King \& H.Rob). Weed Spotters Newsletter Autumn 3:5-6.

Inderjit, Keating KI (1999). Allelopathy: principles, procedures, processes, and promises for biological control. In: Sparks DL (Ed). Advances in Agronomy. Academic Press, New York pp 141-231.

Intanon S, Reed RL, Stevens JF, Hulting AG, Mallory-Smith CA (2014). Identification and phytotoxicity of a new glucosinolate breakdown product from meadowfoam (Limnanthes alba) seed meal. Journal of Agricultural and Food Chemistry 62:7423-7429.

ISTA (2016). International rules for seed testing. The International Seed Testing Association, Zurich, Switzerland.

King RM, Robinson H (1987). The genera of the Eupatorieae (Asteraceae). Monographs in Systematic Botany Vol. 22. Missouri Botanical Garden Press, St. Louis, USA.

Lamsal A, Devkota MP, Shrestha DS, Joshi S, Shrestha A (2019). Seed germination ecology of Ageratum houstonianum: A major invasive weed in Nepal. PLoS One 14:1-14.

Lu P, Sang W, Ma K (2006). Effects of environmental factors on germination and emergence of crofton weed (Eupatorium adenophorum). Weed Science 54:452-457.

Maia GLA, Falcão-Silva VS, Aquino PGV, Araújo-Júnior JX, Tavares JF, Silva MS, ... Barbosa-Filho JM (2011). Flavonoids from Praxelis clematidea R.M. King and Robinson modulate bacterial drug resistance. Molecules $16: 4828-4835$.

Meyer SE, Carlson SL (2001). Achene mass variation in Ericameria nauseosus (Asteraceae) in relation to dispersal ability and seedling fitness. Functional Ecology 15:274-281.

Miller DA (1996). Allelopathy in forage crop systems. Agronomy Journal 88:854-859.

Moles AT, Ackerly DD, Webb CO, Tweddle JC, Dickie JB, Westoby M (2005). A brief history of seed size. Science 307:576-580.

Monaco TJ, Weller SC, Ashton FM (2002). Weed science: Principles and practices. Jon Wiley \& Sons (4th ed), NewYork.

Omami EN, Haigh AM, Medd RW, Nicol HI (1999). Changes in germinability, dormancy, and viability of Amaranthus retroflexus as affected by depth and duration of burial. Weed Research 39:345-354.

Patsai S (2011). Allelopathic effect of Praxelis clematidea (Griseb.) R.M.King \& H.Rob on germination and growth of some crops (in Thai). MSc Dissertation, Srinakharinwirot University, Bangkok, Thailand.

Peachey RE, Mallory-Smith C (2017). Influence of winter seed position and recovery date on hairy nightshade (Solanum sarrachoides) recruitment and seed germination, dormancy, and mortality. Weed Science 55:49-59.

Plant Protection Research and Development (2005). Guidebook: Weed management and herbicide application in 2004 (in Thai). The Agricultural Cooperative Federation of Thailand, Limited (1st ed), Bangkok, Thailand.

R Core Team (2018). R: A language and environment for statistical computing. R Foundation for Statistical Computing, Vienna, Austria. https://www.R-project.org/

Rice EL (1984). Allelopathy. Academic Press (2nd ed), New York.

Sakai AK, Allendorf FW, Holt JS, Lodge DM, Molofsky J, Kimberly AW, ... Weller SG (2001). The population biology of invasive species. Annual Review of Ecology and Systematics 32:305-332.

TH-BIF (2018). Office of Environmental Policy and Planning, Ministry of Science, Technology and Environment of the Government of Thailand: Thailand Biodiversity Information Facility. Retrieved 2019 February 22 from http://thbif.onep.go.th

Thepphakhun T, Intanon S (2016). Allelopathy effect of Praxelis clematidea extract on seed germination and growth of leaf mustard and rice (in Thai). In: Proceedings of the 14th Kaset Naresuan Conference, Faculty of Agricultural Resources and Environment, Naresuan University, Phitsanulok, Thailand pp 171-176.

TMD (2018). Thai Meteorological Department. Retrieved 2018 March 15 from https://www.tmd.go.th

USDA (2014). Weed risk assessment for Praxelis clematidea R.M.King \& H.Rob (Asteraceae)-Praxelis. Retrieved 2016 May 22 from https://www.aphis.usda.gov

Vanijajiva O (2014). Effect of ecological factors on seed germination of alien weed Tridax procumbens (Asteraceae). Journal of Agriculture and Ecology Research 1:30-39.

Veldkamp JF (1999). Eupatorium catarium, a new name for Eupatorium clematideum Griseb. non Sch.Bip (Compositae), a South American species naturalized and spreading in SE Asia and Queensland, Australia. Gardens' Bulletin Singapore 51:119-124. 
Vitousek PM, D'Antonio CM, Loope LL, Westbrooks R (1996). Biological invasions as global environmental change. American Scientist 84:218-228.

Wang ZH, Christie P, Chen QB, Liu XX, Xie LL, Bai CJ, Li XL (2006). Allelopathic potential and chemical constituents of volatile oil from Praxelis clematidea. Allelopathy Journal 18:225-235.

Waterhouse B, McFadyen R, Holland A, Thorp J (2003). Weed management guide: PraxelisPraxelis clematidea. CRC Weed Management. Retrieved 2018 June 15 from http://www.environment.gov.au/biodiversity/invasive/weeds/publications/guidelines/alert/p-clematidea.html

Woolley JT, Stoller EW (1978). Light penetration and light-induced seed germination in soil. Plant Physiology 61:597600.

Yuan X, Wen B (2018). Seed germination response to high temperature and water stress in three invasive Asteraceae weeds from Xishuangbanna, SW China. PLoS One 13:1-16.


The journal offers free, immediate, and unrestricted access to peer-reviewed research and scholarly work. Users are allowed to read, download, copy, distribute, print, search, or link to the full texts of the articles, or use them for any other lawful purpose, without asking prior permission from the publisher or the author.

License - Articles published in Notulae Botanicae Horti Agrobotanici Cluj-Napoca are Open-Access, distributed under the terms and conditions of the Creative Commons Attribution (CC BY 4.0) License.

(C) Articles by the authors; UASVM, Cluj-Napoca, Romania. The journal allows the author(s) to hold the copyright/to retain publishing rights without restriction. 